\title{
Studi terhadap Efektivitas Mediasi dalam Menyelesaikan Perkara Perceraian di Pengadilan Agama Kelas I B Argamakmur Bengkulu Utara
}

\section{A Study on the Effectiveness of Mediation in Settling Divorce Cases in Religious Courts Class I B Argamakmur North Bengkulu}

\section{YOYON EDI}

Universitas Muhammadiyah Bengkulu, email: yoyon.e@gmail.com

\begin{abstract}
ABSTRAK
Pada dasarnya upaya mediasi ini adalah salah satu cara menyelesaikan sengketa yang dilakukan tanpa melalui proses peradilan, melainkan melibatkan para hakim sebagai mediator baik dari pihak suami maupun mediator yang disediakan oleh pihak Pengadilan Agama Arga Makmur Bengkulu Utara itu sendiri. Sehingga keputusan yang diambil oleh para pihak yang sedang bersengketa. Apabila upaya mediasi dalam menyelesaikan perkara dapat menghasilkan keseoakatan maka pihak Pengadilan Agama akan menguguhkan kesepakatan dalam sebuah akta perdamaian. Tujuan penelitian ini adalah untuk mengetahui prosedur peradapan sistem mediasi dalam menyelesaikan perkara perceraian di Pengadilan Agama Argamakmur Bengkulu Utara, untuk mengetahui kendalakendala dalam menyelesaikan perkara perceraian melalui proses mediasi di Pengadilan Agama Argamakmur Bengkulu Utara, dan untuk mengetahui sejauh mana efektivitas sistem mediasi dalam menyelesaikan perkara perceraian di Pengadilan Agama Argamakmur Bengkulu Utara. Metode penelitian yang digunakan metode pendekatan Deskriptif Analistis. Kesimpulan Prosedur penyelesaian perkara perceraian melalui proses mediasi di Pengadilan Agama Argamakmur, terlebih dahulu harus mengajukan gugatan ke Pengadilan Agama tersebut, kemudian setelah persyaratan yang ditentukan oleh Pengadilan Agama sudah terpenuhi, maka ada persidangan pertama majelis hakim menawarkan penyelesaian perkara perceraian kepada para pihak, atau sepanjang proses persidangan berlangsung, tetapi sebelum akan dijatuhkan keputusan oleh Hakim.
\end{abstract}

Kata Kunci: Efektivitas, Mediasi, Perceraian, Pengadilan Agama.

\section{Abstract}

Basically this mediation effort is one of the ways of resolving the dispute made without going through the judicial process, but involves the judges as mediators both as husband and mediators provided by the Religious Court of Arga Makmur North Bengkulu. If the mediation effort in settling matters can result an agreement, so the Religious Court will accord an agreement in a peace treaty. The purpose of this research is to know the procedure of mediation system in settling the divorce case in Religious Court of 
Argamakmur North Bengkulu, to know the obstacle in settling the divorce case through mediation process at Religious Court of Argamakmur North Bengkulu, and to know how far the effectiveness of mediation system in settling divorce case at Religious Court of Argamakmur North Bengkulu. The research method used is Descriptive Analytical Approach method. The conclusion of the divorce settlement procedures through the mediation process at the Religious Court of Argamakmur are: firstly, propose a lawsuit to the Religious Courts, after the requirements determined by the Religious Courts have been fulfilled, then there is the first trial of the judges to offer the settlement of divorce cases to the parties, or as long as the trial process takes place, but before the Judge make a decision.

\section{Keywords: Effectiveness, Mediation, Divorce, Religious Court.}

\section{PENDAHULUAN}

Dalam rangka untuk mengakhiri perkawinan dengan perceraian, harus melalui proses persidangan di pengadilan Agama. Namun demikian sebelum proses gugatan perceraian dilaksanakan dalam proses persidangan, maka hakim terlebih dahulu menawarkan upaya mediasi (perdamaian). ${ }^{1}$

Kemudian upaya melakukan mediasi ini, berdasarkan pasal 7 Peraturan Mahkamah Agung nomor 1 tahun 2008, menegaskan :

1) Pada hari sidang yang tleah ditentukan yang di kondisi kedua belah pihak, hakum mewajibkan para pihak untuk menempuh mediasi.

2) Ketidakhadiran pihak turut tergugat tidak menghalangi pelaksanaan mediasi.

1 A. Mukti Arto, 1999. Praktik Perkara Perdata pada pengadilan Agama, Yogyakarta, Pustaka Pelajar, halaman 93
3) Hakim melalui kuasa hukum atau langsung kepada para pihak, mendorong para pihak untuk berperan langsung atau aktif dalam proses mediasi.

4) Kuasa hukum para pihak berkewajiban untuk mendorong para pihak sendiri berperan langsung atau aktif dalam proses mediasi.

5) Hakim wajib menenda proses persidangan perkara untuk memberikan kesempatan kepada para pihak menempuh proses mediasi.

Berdasarkan penelitian awal yang penulis lakukan di Pegadilan Agama Arga Makmur Bengkulu Utara dapat diketahui bahwa dalam mengadili perkara perceraian hakim terlebih dahulu menawarkan upaya mediasi. Pada dasarnya upaya mediasi ini adalah 
Studi Terhadap Efektifitas Mediasi dalam Menylesaikan Perkara Perceraian

Di Pengadilan Agama Kelas I B Argamakmur Bengkulu Utara

salah satu cara penyelesaian sengketa yang dilakukan tanpa melalui proses peradilan, melainkan melibatkan para hakim sebagai mediator baik dari pihak suami maupun mediator yang telah disediakan oleh pihak Pengadilan Agama Arga Makmur Bengkulu Utara itu sendiri. Sehingga keputusan yang diambil oleh para pihak melalui peranan mediator tersebut benar-benar dilahirkan dari kesepakatan para pihak yang sedang bersengketa.

Kemudian lain halnya, apabila suatu sengketa itu diproses melalui perantaraan pengadilan, maka keputusan yang dijatuhkan oleh hakim itu bukan didapat dari hasil kesepakatan, melainkan melalui pengajuan dan penilaian alat-alat di persidangan. Jadi penyelesaian suatu persengketaan dengan perantaraan pengadilan sebenarnya tidak dapat dikatakan cara yang sudah paling tepat disangka kebanyakan orang. Berkenaan dengan hal ini secara gamblang dikatakan oleh Victor M. Sitomorang "menyelesaikan suatu perkara atau sengketa perdata dengan melalui perantaraan keputusan pengadilan harus dipandang sebagai cara yang formal saja sekedar lebih terpuji dair pada menghakimi sendiri, jadi bukanlah suatu cara yang paling baik atau cocok dan tepat". ${ }^{2}$

Apabila upaya mediasi dalam menyelesaikan perkara dapat menghasilkan kesepakatan maka pihak Pengadilan Agama akan mengukuhkan kesepakatan dalam sebuah akta perdamaian. Dengan adanya akta perdamaian maka gugatan dicabut dan proses persidangan tidak dilanjutkan. Tetapi sebaliknya apabila proses mediasi ini gagal mencapai kesepakatan, maka proses persidangan akan dilanjutkan dengan pemeriksaan surat gugatan dan pengajuan ala-alat bukti untuk membantu hakim dalam memberikan keputusan terhadap perkara tersebut.

Berdasarkan latar belakang masalah yang telah diungkapkan diatas, maka penulis tertarik untuk menelitinya dalam sebuah karya ilmiah yang berbentuk artikel penelitian dengan rumusan masalah adalah : Bagaimana prosedur penerapan sistem mediasi dalam menyelesaikan perkara perceraian di Pengadilan Agama Arga Makmur Bengkulu Utara? Kendalakendala dalam penyelesaian perkara

${ }^{2}$ Victor Sitomorang, 1997. Arbitrase dan Perdamaian, Jakarta : Sinar Grafika. Halaman 2 
perceraian melalui proses di Pengadilan Agama Arga Makmur Bengkulu Utara ?

1. Sejauh mana efektivitas mediasi dalam menyelesaikan perkara perceraian di Pengadilan Agama Arga Makmur Bengkulu Utara ?]

\section{METODE PENELITIAN}

Dalam rangka untuk mendapatkan hasil laporan penelitian sesuai dengan yang diharapkan, maka diperlukan adanya upaya-upaya, guna membahas permasalahan yang ada, maka penulis menggunakan metode penelitian sebagai berikut.

Penulis memilih lokasi di Pengadilan Agama Arga Makmur Bengkulu Utara dengan pertimbangan, untuk mempermudah memperoleh data-data atau perkara-perkara perceraian yang diselesaikan melalui sistem mediasi.

Penelitian ini menggunakan metode pendekatan yuridis sosiologis. Digunakannya metode ini karena hukum yang dipelajari dan diteliti sebagai suatu studi mengenai law in action. Pendekatan yuridis sosiologis ini dimaksudkan untuk menggambarkan dan menganalisa secara jelas dan rinci tentang efektifitas sistem mediasi dalam menyelesaikan perkara perceraian di Pengadilan Agama Arga Makmur Bengkulu Utara.. Pendekatan yuridis sosiologis ini berdasarkan pada penelitian yang dilakukan terhadap keadaan nyata di masyarakat atau lingkungan masyarakat dengan maksud dan tujuan untuk menemukan fakta, kemudian dilanjutkan dengan menemukan masalah dan pada akhirnya kepada penyelesaian masalah. ${ }^{3}$

\section{PEMBAHASAN}

Prosedur Sistem Mediasi Dalam Menyelesaikan Perkara Gugatan Perceraian Karena Alasan Syiqaq

Sebagaimana diketahui bahwa mediasi yang dilakukan melalui Pengadilan Agama Kelas IA Argamakmur telah terjadi begitu saja, sebab dalam menyelesaikan setiap perkara, maka pihak Pengadilan Agama Kelas IA Argamakmur, akan dapat melaksanakan tugasnya setelah ada permohonan atau gugatan dari pihak yang berperkara. Hal ini disebabkan adanya aturan yang mengikat, yaitu pasal 55 Undang-undanag Nomor 7 Tahun 1989, setiap pemeriksaan perkara di Pengadilan dimulai sesudah diajukannya suatu permohonan atau gugatan dari pihakpihak yang berperkara telah dipanggil menurut ketentuan yang berlaku.

3 Soerjono Soekanto, 1990, Pengantar Penelitian Hukum, UI . 
Studi Terhadap Efektifitas Mediasi dalam Menylesaikan Perkara Perceraian

Di Pengadilan Agama Kelas I B Argamakmur Bengkulu Utara

Berdasarkan keterangan pasal di atas jelaskan bahwa pada dasarnya pihak Pengadilan hanya bisa memproses suatu perkara apabila ada permohonan atau gugatan dari pihak yang berpekara. Disamping itu sebagaimana telah diuraikan pada pembahasan terdahulu, bahwa pihak pengadilan dalam menyelesaikan suatu perkara senantiasa mengusahakan mediasi yang dilakukan oleh mediator. Mediasi ini bukan saja dilakukan pada sidang pertama tapi pada tahap-tahap sidang berikutnya sebelum perkara diputus oleh hakim.

Dengan demikian, sebelum proses mediasi ini dilakukan maka prosedur dalam mengajukan gugatan di Pengadilan Agama Kelas IA Argamakmur, juga berlaku terhadap para pihak yang perkaranya akan diselesaikan melalui mediasi. Jadi prosedur dalam mengajukan gugatan ini berlaku terhadap proses perkara perceraian karena syiqaq, baik dengan jalan proses persidangan maupun dalam proses mediasi.

Adapun cara-cara yang dilakukan dalam proses penyelesaian perkara syiqaq melalui mediasi, adalah sebagai berikut :

1. Pengajuan gugatan di Pengadilan Agama Kelas IA Argamakmur

Surat gugatan perceraian yang telah dibuat dan ditandatangani itu, diajukan kepaniteraan gugatan di Pengadilan Agama dimana tergugat bertempat tinggal, yaitu pada bagian kepaniteraan gugatan. Kemudian penggugat menghadap ke meja pertama yang akan menaksir besarnya panjar biaya perkara yang harus dibayar oleh penggugat (Sri Andini, Juru Sita, wawancara, tanggal 2 Juni 2010).

Adapun besarnya panjar biaya perkara (tersebut) diperkirakan harus telah mencakup untuk menyelesaikan perkara tersebut, biaya-biaya yang harus dibayar adalah :

a. Biaya kepaniteraan

b. Biaya pemanggilan, pemberitahuan dan lain-lain atas perintah pengadilan.

c. Biaya yang harus dibayar kepada panitera atau juru sita karena menjalankan keputusan atau ketetapan.

Berkenaan dengan biaya perkara yang harus dibayar oleh penggugat sebagaimana yang telah disebutkan di atas, hal itu tidak bersifat mutlak. Dengan perkataan lain apabila seseorang ingin mengajukan gugatan tetapi tidak mampu (miskin), maka ia dapat mengajukan gugatan secara cuma-cuma atau dibebaskan dari biaya 
perkara. Dalam hal ini dijelaskan oleh Nadhifah (Hakim, wawancara, tanggal 3 Juni 2010). Memang pada dasarnya seseorang yang akan berperkara di Pengadilan Agama Kelas IA Argamakmur dikenakan biaya perkara, namun demikian jika penggugat tidak mempunyai biaya atau dikategorikan orang miskin, maka dapat berperkara secara cuma-cuma. Tetapi kemiskinan tersebut harus dibuktikan dengan melampirkan surat keterangan miskin dari Lurah atau Kepala Desa dan dilegalisir oleh camat.

Kemudian berkenaan dengan ukuran atau besarnya biaya perkara ini diungkapkan oleh Risani (Panitera Penggantia, wawancara, tanggal 3 Juni 2010). Pada dasarnya tidak dapat ditentukan berapa jumlah yang maksimal dan minimal hal ini sangat tergantung dari lama atau tidaknya proses persidangan itu sendiri. Hal ini berarti besarnya nilai nominal biaya perkara belum dapat ditentukan sebelum hakim memutus perkara pihak mana yang menang dan kalah demikian juga halnya dengan verskot (uang panjar) tidak dapat disebutkan karena sifatnya formil administrasi negara.

2. Pembayaran panjar biaya perkara
Setelah penggugat selesai mengajukan surat gugatan dan penaksiran jumlah biaya perkara dengan membawa surat kuasa untuk membiayai, maka calon penggugat kemudian menghadap kepada kasir dengan menyerahkan surat gugatan dan surat membayar. Penggugat membayar panjar biaya perkara sesuai dengan yang tertera pada surat kuasa untuk membayar tersebut. Kemudian kasir menerima uang tersebut dan mencatat dalam jurnal biaya perkara. Menandatangani dan memberi nomor perkara serta tanda lunas pada surat kuasa untuk membayar, selanjutnya mengembalikan surat gugatan dan surat kuasa untuk membayar kepada calon penggugat. Risani (Panitera Pengganti, wawancara, tanggal 31 Mei 2010).

3. Pendaftaran gugatan

Surat gugatan harus jelas dan mendukung apa yang digugat oleh penggugat, dengan perkataan lain surat gugatan tersebut mudah dimengerti dan dapat diterima oleh pengadilan agama, sebagaimana diungkapkan oleh Risani (Panitera Pengganti, wawancara, tanggal 31 Mei 2010). 
Studi Terhadap Efektifitas Mediasi dalam Menylesaikan Perkara Perceraian

Di Pengadilan Agama Kelas I B Argamakmur Bengkulu Utara

Apabila seorang ingin mengajukan gugatan ke pengadilan agama, maka setiap peristiwa atau kejadian-kejadian yang mendukung adanya hubungan hukum digambarkan atau diungkapkan secara kronologis dan sistematis. Hal ini dimaksudkan untuk memudahkan hakim dalam menilai atau menimbang sebelum mengambil kesimpulan, apakah dasar gugatan itu menjadi penyebab sebagai alasan penggugat untuk meminta supaya majelis hakim mengabulkan gugatannya.

Memperhatikan surat gugatan tersebut harus jelas dan terarah, hal ini dimaksudkan dalam rangka untuk memperlancar dan mempercepat proses persidangan sehingga majelis hakim dapat mengerti dan memahami apa yang diminta dan diharapkan oleh penggugat. Berkenaan dengan hal ini dijelaskan oleh Sri Andini (Juru Sita, wawancara, tanggal 31 Mei 2010).

Dalam rangka mengantisipasi dan menghindari surat gugatan yang tidak jelas dan tidak terarah, maka panitera pengganti akan meneliti dengan secermat mungkin surat gugatan tersebut dan memberikan beberapa catatan kepada penggugat agar surat gugatan dirubah kalimatnya, baik ditambah atau dikurangi, serta memberikan masukan kepada calon penggugat setelah mendengarkan keterangan dari calon penggugat.

Kemudian jika persyaratan gugatan telah lengkap termasuk isinya telah jelas dan terarah, maka surat gugatan tersebut diserahkan kepada petugas di kepaniteraan bagian gugatan dan diberi nomor pada surat gugatan sesuai dengan nomor yang telah diberikan oleh kasir, selanjutnya surat gugatan itu diparaf sebagai tanda bukti bahwa gugatan itu telah didaftarkan. Lalu memasukkan surat gugatan dalam map berkas perkara dan menyerahkan kepada wakil panitera untuk disampaikan kepada Ketua Pengadilan Agama untuk diproses.

4. Penetapan majelis hakim

Setelah surat gugatan terdaftar di kepaniteraan Pengadilan Agama, maka panitera wajib secepatnya menyampaikan berkas itu kepada Ketua Pengadilan Agama. Selanjutnya Ketua Pengadilan Agama akan menunjuk atau menetapkan majelis 
hakim yang akan menyimak dan mengadili perkara tersebut.

Pada dasarnya majelis hakim itu terdiri dari tim hakim yang terdiri dari tiga orang hakim, seorang bertindak sebagai ketua majelis hakim dan yang lainnya bertindak sebagai hakim anggota dan dibantu oleh seorang panitera atau panitera pengganti. Sebagaimana diatur di dalam pasal 17 Undang-undang Nomor 4 Tahun 2004, tentang kekuasaan kehakiman yang berbunyi :

1. Semua pengadilan memeriksa dan memutuskan dengan sekurang-kurangnya tiga orang hakim, kecuali undangundang menentukan lain.

2. Diantara para hakim tersebut dalam ayat (1) seorang bertindak sebagai ketua dan lainnya sebagai anggota sidang.

3. Sidang dibantu oleh panitera atau seorang yang ditugaskan melakukan pekerjaan penitera.

\section{Penetapan hari sidang}

Setelah perkara masuk dan didaftarkan di kepaniteraan pengadilan agama, maka ketua majelis hakim yang telah ditunjuk untuk memeriksa perkara tersebut, menetapkan hari dan jam perkara itu akan diperiksa di muka persidangan. Dalam menetapkan hari dan jam sidang itu harus diperhatikan kelayakan, artinya ketentuan majelis hakim harus memperhatikan jarak antara tempat tinggal para pihak yang berperkara dan tempat pengadilan agama itu bersidang.

Kemudian kepada penggugat perkara perceraian karena syiqaq diberitahukan bahwa setelah mengetahui hari sidang, maka harus mempersiapkan saksi-saksi untuk memperkuat atau mendukung gugatan yang diajukan pada pengadilan agama.

6. Pemanggilan terhadap para pihak

Berdasarkan perintah hukum ketua majelis. Maka juru sita atau juru sita pengganti melaksanakan pemanggilan kepada para pihak supaya hadir di persidangan pada hari, tanggal dan jam sebagaimana dalam penetapan hari sidang oleh ketua majelis hakim. Adapun tata cara pemanggilan para pihak adalah sebagai berikut :

Pemanggilan kepada para pihak dilakukan oleh juru sita atau juru sita pengganti, dimana tergugat dipanggil di tempatnya, apabila di 
Studi Terhadap Efektifitas Mediasi dalam Menylesaikan Perkara Perceraian

Di Pengadilan Agama Kelas I B Argamakmur Bengkulu Utara

tempatnya tidak dijumpai, maka pemanggilan itu disampaikan lewat kepala desa atau lurah setempat. Jarak antara pemanggilan dan hari persidangan harus memenuhi tenggang waktu yang patut, yakni sekurang-kurangnya tiga hari sebelum sidang dimulai (Risani, Panitera Pengganti, wawancara, tanggal 31 Mei 2010).

Berkenaan dengan pelaksanaan pemanggilan terhadap para pihak yang dilakukan oleh juru sita pengadilan agama, apabila salah pihak tidak hadir pada hari sidang pertama yang telah ditentukan, biasanya majelis hakim akan memanggil sekali lagi terhadap pihak yang tidak hadir tersebut, dalam hal ini dijelaskan oleh Risani (Panitera Pengganti, wawancara, tanggal 31 Mei 2010).

Pemanggilan terhadap para pihak dengan patut dilakukan oleh juru sita, sangat penting dalam proses persidangan di pengadilan agama, apabila surat pemanggilan kepada para pihak itu diberikan atau dititipkan kepada sembarang orang, maka dikhawatirkan surat pemanggilan itu tidak sampai kepada para pihak. Sehingga para pihak tidak mengetahui bahwa ia dipanggil untuk mengikuti proses persidangan. Namun demikian apabila salah satu pihak tidak hadir pada hari persidangan yang telah ditetapkan, maka majelis hakim akan memanggil kembali kepada salah satu pihak yang tidak hadir. Hal ini berarti majelis hakim akan menunda hari persidangan sekali lagi untuk memanggil pihak yang tidak hadir tersebut.

Selanjutnya apabila para pihak tidak hadir setelah dipanggil untuk kedua kalinya dan juga tidak mengirim atau menyuruh wakilnya untuk hadir guna memberitahukan penyebab salah satu pihak tidak hadir tersebut. Padahal sudah dipanggil dengan patut atau resmi, maka akibat hukumnya :

1. Terhadap pihak penggugat

Apabila penggugat tidak hadir setelah dipanggil secara patut atau resmi untuk kedua kalinya, maka surat gugatannya dinyatakan gugur dan dia di hukum untuk membayar biaya perkara, tetapi ia berhak untuk mengajukan surat gugatannya itu sekali lagi.

2. Terhadap pihak tergugat 
Apabila tergugat tidak hadir dan tidak menyuruh wakilnya untuk hadir menginformasikan alasan ketidakhadiran tergugat, setelah dipanggil untuk kedua kalinya maka majelis hakim akan memutuskan perkara gugatan tersebut dengan putusan verstek (putusan di luar hadirnya tergugat). Apabila pihak tergugat tidak melakukan perlawanan (verzet), maka keputusan hakim dalam mengabulkan gugatan tergugat dapat dilaksanakan (Risani, Panitera Pengganti, wawancara, tangga 31 Mei 2010).

Sebagaimana telah dikemukakan di atas, bahwa anjuran mediasi atau perdamaian dalam menyelesaikan perkara perceraian karena alasan syiqaq ini, dapat dilakukan kapan saja sepanjang perkara belum diputus, tetapi anjuran mediasi pada permulaan sidang terutama adalah bersifat wajib, sebagaimana ditegaskan di dalam pasal 3 ayat 1 dan 2 Peraturan Mahkamah Agung Nomor 2 Tahun 2003.

(1) Pada hari sidang pertama yang dihadiri kedua belah pihak, hakim mewajibkan para pihak yang berperkara agar lebih dahulu menempuh mediasi.

(2) Hakim wajib menunda persidangan perkara itu untuk memberikan kesempatan kepada para pihak menempuh proses mediasi.

Kemudian setelah ketua majelis hakim menganjurkan kepada pra pihak (suami isteri) untuk menyelesaikan persengketaan mereka dengan jalan mediasi (perdamaian), maka ada beberapa hal yang harus diperhatikan oleh para pihak sebelum proses mediasi dilakukan antara lain, yaitu :

1. Berdasarkan ketentuan pasal 4 Peraturan Mahkamah Agung, menegaskan :

(1) Dalam waktu paling lama satu hari kerja setelah sidang pertama, para pihak dan atau kuasa hukum mereka wajib berunding guna memilih mediator dari daftar mediator yang dimiliki oleh pengadilan atau mediator di luar daftar pengadilan.

(2) Jika dalam waktu satu hari kerja para pihak atau kuasa hukum mereka tidak dapat sepekat tentang penggunaan mediator di dalam atau di luar daftar pengadilan, para pihak wajib memilih mediator dari daftar mediator yang disediakan oleh pengadilan tingkat pertama.

(3) Jika dalam satu hari kerja para pihak tidak dapat bersepakat dalam 
Studi Terhadap Efektifitas Mediasi dalam Menylesaikan Perkara Perceraian

Di Pengadilan Agama Kelas I B Argamakmur Bengkulu Utara

memilih seorang mediator dari daftar yang disediakan oleh pengadilan, ketua majelis berenang untuk menunjuk seorang mediator dari daftar mediator dengan penetapan.

2. Berdasarkan ketentuan pasal 5 Peraturan Mahkamah Agung, menegaskan :

(1) Proses mediasi yang menggunakan mediator di luar daftar mediator yang dimiliki oleh pengadilan, berlangsung paling lama tiga puluh hari kerja.

(2) Setelah waktu tiga puluh hari kerja terpenuhi para pihak wajib menghadap kembali pada hakim pada sidang yang ditentukan.

(3) Jika para pihak mencapai kesepakatan, mereka dapat meminta penetapan dengan suatu akta perdamaian.

(4) Jika para pihak berhasil mencapai kesepakatan yang tidak dimintakan penetapannya sebagai suatu akta perdamaian, pihak penggugat wajib menyatakan pencabutan gugatannya.

Kemudian dalam tahap proses mediasi ini, ada beberapa hal yang perlu dilakukan oleh mediator, antara lain :
1. Dalam jangka waktu paling lama tujuh hari kerja, setelah para pihak menentukan atau menunjuk mediator yang akan membantu dalam penyelesaian kasus perceraian karena syiqaq dengan mediasi, maka para pihak wajib menyerahkan foto copy dokumen (surat gugatan) yang memuat duduk perkara, foto copy surat-surat yang diperlukan kepada mediator.

2. Kemudian mediator menentukan jadwal pertemuan untuk penyelesaian proses mediasi, sedangkan untuk tempat dalam proses mediasi itu diserahkan kepada para pihak untuk memilihnya. Apabila dilakukan di salah satu ruangan di Pengadilan Agama Kelas IA Argamakmur tidak dikenakan biaya, tetapi apabila dilakukan di tempat lain di luar Pengadilan Agama Kelas IA Argamakmur biaya sewa tempat ditanggung oleh para pihak.

3. Apabila para pihak tidak dapat mengikuti proses mediasi, maka dapat dikuasakan kepada kuasa hukumnya, setiap keputusan yang diambil oleh kuasa hukum wajib memperoleh persetujuan tertulis dari para pihak.

4. Dalam proses mediasi para pihak (suami isteri) dapat didampingi oleh kuasa hukumnya. 
5. Sedangkan jangka waktu yang diberikan kepada mediator untuk menyelesaikan perkara perceraian karena alasan syiqaq dengan mediasi ini, selama dua puluh dua hari kerja sejak penetapan penunjukan mediator. Jadi selama jangka waktu dua puluh hari tersebut, proses mediasi akan diketahui, baik tercapai kesepakatan atau tidak ada kesepakatan. (Nadhifah, Hakim, wawancara, tanggal 1 Juni 2010).

Selanjutnya apabila mediator telah berhasil menyelesaikan perkara perceraian karena alasan syiqaq melalui mediasi, maka pada sidang berikutnya hasil mediasi tersebut disampaikan kepada hakim pada hari sidang telah ditentukan. Berkenaan dengan hal ini ditegaskan oleh Nadhifah :

Apabila proses mediasi dalam menyelesaikan perkara perceraian karena alasan syiqaq tersebut, menghasilkan kesepakatan dengan bantuan mediator, para pihak (suami isteri) diwajibkan untuk merumuskan secara tertulis kesepakatan yang telah tercapai itu dan ditandatangani oleh suami isteri yang berperkara itu. Kemudian setelah kesepakatan yang dirumuskan oleh para pihak ditandatangani, maka para pihak wajib menghadap kembali. Pada hakim pada hari sidang yang telah ditentukan untuk memberitahukan telah tercapainya kesepakatan dan hakim akan menetapkan kesepakatan sebagai akta perdamaian (Nadhifah, Hakim, wawancara, tanggal 1 Juni 2010).

Kemudian hal senada dikatakan oleh Fauzah :

Pada dasarnya penyelesaian suatu perkara melalui mediasi merupakan cara yang terbaik, sebab keputusan yang akan diambil berdasarkan kesepakatan para pihak. Oleh karena itu penyelesaian perkara melalui mediasi ini, tidak terlepas dari peranan mediator yang dapat mempersatukan perbedaan antara kedua belah pihak yang bersengketa. Jika mediator telah berhasil mencapai kesepakatan, maka kesepakatan itu dirumuskan dalam bentuk akta perdamaian dan ditandatangani oleh para pihak. Selanjutnya pada hari sidang berikutnya yang telah telah ditentukan untuk dikukuhkan atau ditetapkan oleh hakim (Fauzah, Hakim, wawancara, tanggal 2 Juni 2010). 
Studi Terhadap Efektifitas Mediasi dalam Menylesaikan Perkara Perceraian

Di Pengadilan Agama Kelas I B Argamakmur Bengkulu Utara

Mencermati tentang pelaksanaan penyelesaian perkara perceraian karena alasan syiqaq melalui mediasi, sebagaimana dijelaskan di atas, hal itu sangat tergantung dari peranan dari mediator dalam memberikan nasehat dan pandangan kepada para pihak (suami isteri) dan juga kesadaran dan kesungguhan dari para pihak itu sendiri untuk menyelesaikan perkara perceraian karena alasan syiqaq melalui mediasi. Oleh karena itu para pihak diperintahkan oleh hakim untuk menepati atau mentaati isi mediasi (perdamaian) yang telah ditetapkan oleh hakim tersebut. Sehubungan dengan penetapan akta perdamaian yang telah disepakati oleh para pihak melalui mediasi, dikatakan oleh Nadhifah :

Keberadaan akta perdamaian melalui proses mediasi, bukanlah ketetapan yang diambil atas tanggung jawab hakim, melainkan sebagai persetujuan atau kesepakatan antara kedua belah pihak melalui juru runding atau mediator. Dengan demikian walaupun penetapan akta perdamaian tersebut, bukan melalui proses persidangan pengadilan tetapi melalui proses mediasi, maka kekuatan hukum dari akta perdamaian itu sama halnya dengan perkara perceraian yang diselesaikan melalui proses persidangan, dan akibat hukumnya mengikat terhadap para pihak (Nadhifah, Hakim, wawancara, tanggal 3 Juni 2010).

\section{Perkara-Perkara Yang Diselesaikan Melalui Sistem Mediasi}

Pada dasarnya pertengkaran dimulai dengan sebab-sebab yang sepele dan apinya membesar atau dalam jiwa suami bergejolak faktor-faktor psikis atau pemicu dari luar yang membuatnya beranggapan bahwa perkawinan itu merupakan api neraka. Namun terkadang kebengkakan (gejolak) itu datangnya dari pihak isteri, lalu ia berlebihan dalam tuntutannya dan menutup mata dari kekurangan suami atau membandingkan dengan orang lain yang lebih kaya.

Konflik dalam rumah itu dapat dikatakan sebagai gelombang kehidupan suami isteri, terkadang dari gelombang kehidupan itu ada yang dapat diatasi dan ada yang terjadi secara terus menerus. Sehingga keharmonisan dan ketentraman dalam rumah tangga tidak terwujud, kondisi rumah tangga yang selalu diwarnai oleh pertengkaran. Menurut Djamil Latif (1993 : 70), pertengkaran atau suatu perselisihan yang telah terjadi demikian hebat antara suami isteri disebut dengan 
syiqaq. Sedangkan pengertian syiqaq menurut penjelasan pasal 76 (1) Undangundang Nomor 7 Tahun 1989, adalah perselisihan yang tajam dan terus menerus antara suami isteri.

Berdasarkan keterangan di atas, maka dapat dipahami bahwa apabila dalam rumah tangga itu sudah tidak tercipta lagi keharmonisan atau antara suami isteri itu selalu bertengkar, tentu saja kondisi rumah tangga seperti ini kalau tetap dipertahankan akan lebih banyak mudharatnya, oleh karena itu perkawinan tersebut harus diakhiri. Jadi, keberadaan tersebut merupakan salah satu alasan untuk mengakhiri perkawinan dengan perceraian.

Sebagaimana diketahui bahwa mediasi yang dilakukan melalui Pengadilan Agama Kelas IA Argamakmur telah terjadi begitu saja, sebab dalam menyelesaikan setiap perkara, maka pihak Pengadilan Agama Kelas IA Argamakmur, akan dapat melaksanakan tugasnya setelah ada permohonan atau gugatan dari pihak yang berperkara. Hal ini disebabkan adanya aturan yang mengikat, yaitu pasal 55 Undang-undanag Nomor 7 Tahun 1989, setiap pemeriksaan perkara di Pengadilan dimulai sesudah diajukannya suatu permohonan atau gugatan dari pihak- pihak yang berperkara telah dipanggil menurut ketentuan yang berlaku.

Berdasarkan keterangan pasal di atas jelaskan bahwa pada dasarnya pihak Pengadilan hanya bisa memproses suatu perkara apabila ada permohonan atau gugatan dari pihak yang berpekara. Disamping itu sebagaimana telah diuraikan pada pembahasan terdahulu, bahwa pihak pengadilan dalam menyelesaikan suatu perkara senantiasa mengusahakan mediasi yang dilakukan oleh mediator. Mediasi ini bukan saja dilakukan pada sidang pertama tapi pada tahap-tahap sidang berikutnya sebelum perkara diputus oleh hakim.

Pada dasarnya perkara-perkara yang diselesaikan melalui proses mediasi di Pengadilan Agama Kelas IA Argamakmur, adalah setiap perkara yang masuk di Pengadilan Agama Kelas IA Argamakmur, diantaranya bidang perkawinan, kewarisan, dan sengketa tanah wakaf, apabila hal-hal tersebut itu terjadi persengketaan diantara para pihak, maka senantiasa diadakan proses mediasi (Fauzah, wawancara, tanggal 1 Juni 2010).

Kemudian berdasarkan data yang diperoleh dari hasil penelitian di lapangan, perkara-perkara yang diselesaikan oleh Pengadilan Agama Kelas IA Argamakmur. 
Studi Terhadap Efektifitas Mediasi dalam Menylesaikan Perkara Perceraian

Di Pengadilan Agama Kelas I B Argamakmur Bengkulu Utara

\section{PENUTUP}

Prosedur penyelesaian perkara perceraian melalui proses mediasi di Pengadilan Agama Argamakmur, terlebih dahulu harus mengajukan gugatan ke Pengadilan Agama tersebut, kemudian setelah persyaratan yang ditentukan oleh Pengadilan Agama sudah terpenuhi, maka ada persidangan pertama majelis hakim menawarkan penyelesaian perkara perceraian kepada para pihak, atau sepanjang proses persidangan berlangsung, tetapi sebelum akan dijatuhkan keputusan oleh Hakim. Pelaksanaan sistem mediasi dalam menyelesaikan sistem perkara perceraian di Pengadilan Agama Argamakmur belum terlaksana secara efektif, hal ini di karenakan adanya pengaruh dari hukum adat setempat di mana sebelum mereka mengajukan gugatan ke Pengadilan Agama, proses penyelesaian perceraian telah di lakukan secara adat.

\section{DAFTAR PUSTAKA}

A. Mukti Arto, 1999. Praktik Perkara Perdata pada pengadilan Agama, Yogyakarta, Pustaka Pelajar, halaman 93

Soerjono Soekanto, 1990, Pengantar

Penelitian Hukum, UI .

Victor Sitomorang, 1997. Arbitrase dan

Perdamaian, Jakarta : Sinar Grafika.

Halaman 2 